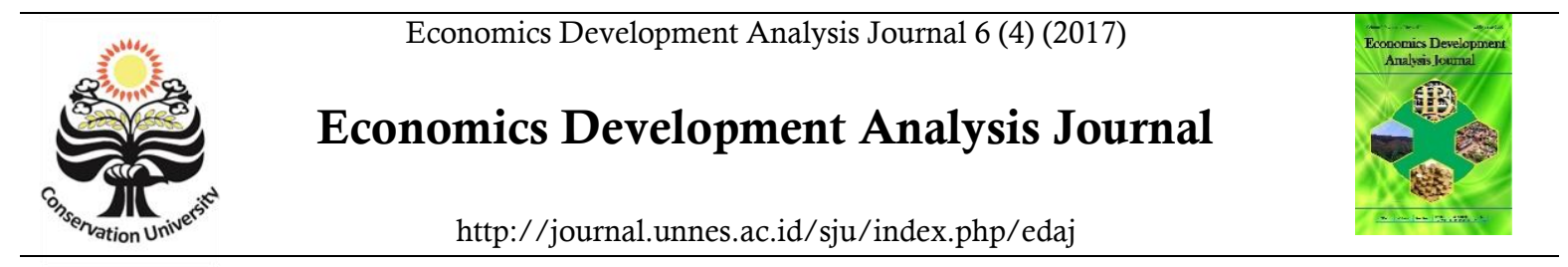

\title{
Valuation and Development Strategy of Mawar Basecamp in Ungaran Mountain Through Individual Travel Cost Approach
}

\author{
Muhammad Izzuddin Furqony ${ }^{1 凶}$, Fafurida $^{2}$
}

Economics Development Department, Economics Faculty, Universitas Negeri Semarang

\begin{tabular}{l} 
Article Info \\
\hline Article History: \\
Received Juny 2017 \\
Accepted Agust 2017 \\
Published November \\
2017
\end{tabular}

Keywords:

Economic Valuation, Individual Travel Cost, SWOT

\begin{abstract}
Mawar basecamp in Ungaran mountain is one of the potential tourist destinations in Semarang regency. This study aims to identify the variables affect the demand of visits. Secondly, to calculate the economic valuations through the travel cost approach and determine the strategies that can be applied to the development of Mawar Basecamp. This study uses multiple linear regression analysis, economic valuation analysis and SWOT analysis. The result shows that access variables, travel motivation and travel cost have significant effect, while income variable has no significant effect to the demand of Mawar Basecamp visit. The result of economic valuation analysis based on travel cost of visitors shows that the total economic valuation is $\mathrm{Rp} 8,212,546,988,73$ per year. Strategy analysis using SWOT shows that the strategies that can be applied are improving facilities and services, preserving and preserving nature, promotion and cooperation with private and government parties.
\end{abstract}

\footnotetext{
$\triangle$ Corresponding Author:

Journal's Room, L Building, FE UNNES Sekaran Gunungpati

Semarang 50229, Indonesia

E-mail: edaj@mail.unnes.ac.id
} ISSN 2252-6965 


\section{INTRODUCTION}

Tourism represents an important domain in the revival and modernization of any economy because businesses are rather small sized and capital needs reduced imprinting investments a fast rhythm (Mirela, 2017). Factors affecting the demand for tourism one of which is income, which is explained that if the income of the country is high, the tendency to have tourist destinations as a place of vacation will be higher and prospective tourists can also make a business on tourist destination, if deemed profitable (Eriyati, 2017). Central Java as one of the provinces in Indonesia that has great potential for tourism. The number of tourist is given to make Central Java as a tourist destination that is visited by many tourists both domestic and foreign tourists. One of the many popular natural attractions today among young people or adults in general is a natural tour to the mountains. This form of tourism in the form of camping, mountain climbing or just come and see the landscape from the altitude.

One of the places that become a destination for nature tourism in the form of mountain climbing and camping area is the Nature Tourism and Mawar Camp Climbing Ungaran or commonly also called Mawar Basecamp. It is located on the slopes of Mount Ungaran precisely in Sidomukti Village, Bandungan Subdistrict, Semarang Regency, Central Java.

Mawar Basecamp is a natural tourist destination located in the forest area of Mount Ungaran which is used as a place for Post Trekking and camping location. This location is still in the process of development stage. Mawar Basecamp are always visited by visitors although access roads to the location is still much damaged, mosque facilities, bathrooms, and stalls are less adequate. The existence of Mawar Basecamp has the potential to be developed in supporting the economic development of surrounding communities.

The large number of visitors coming is certainly influenced by the factors that led to the increasing number of visits to Mawar Basecamp.
Therefore, it is necessary to research about what factors influencing the number of visitors coming to Mawar Basecamp even though condition is still in development stage. The visitor certainly pay the entrance fee, the availability of paying visitors can be determined by analyzing the economic value through individual travel costs incurred by visitors to Mawar Basecamp. The individual travel costs technique estimates the value enjoyed from a past visit. This type of value estimate is not strictly appropriate for use in benefit-cost analyses of investments or policies that will generate future changes in recreational values (Gillespie, 2017).

Based on the research background, this research research try to identify the factors who influence the number of tourist visit in Mawar Camp Area (Mawar Basecamp) Mount Ungaran. Second, how much economic value that obtained through individual travel cost approach. And how to determine the development strategy.

This study aims to analyze what factors affect the demand of Mawar Basecamp visit, calculate the economic valuation through the individual travel cost approach and determine the development strategy for the development of the Mawar Basecamp in the future.

\section{RESEARCH METHOD}

The population in this study are Mawar Basecamp visitors with an average of 3605 visitors per year. While the number of samples obtained bysthe slovin formula is 97 visitors. The sampling method used is quoted accidential sampling, i.e the sampling is done to anyone found in the location but limited in number according to the required sample number of 97 respondents.

This study uses linear regression analysis method with the variable of the number of visits demand as the dependent variable and access variables, income, motivation and travel costs as independent variables. Therefore, to determine the effect of access, revenue, travel motivation and travel costs to the number of requests visit Mawar Basecamp is calculated by unit of Likert 
scale that is obtained from the questionnaire data. The equation as follows:

$$
\mathrm{Y}=\mathrm{f}(\mathrm{X} 1, \mathrm{X} 2, \mathrm{X} 3, \mathrm{X} 4)
$$

Where:

$\begin{array}{ll}\mathrm{Y} & : \text { A visitor demand } \\ \mathrm{X} 1 & : \text { Access } \\ \mathrm{X} 2 & \text { : Travel motivation } \\ \mathrm{X} 3 & \text { : Income } \\ \mathrm{X} 4 & \text { : Travel cost }\end{array}$

The other analysis is economic valuation analysis. This analysis used the method of individual travel costs, namely by calculating the surplus of consumers per individual per year. To calculate the value of consumer surplus, the following formulation is used:

] $\mathrm{VE}=\int_{P 0}^{P 1}(\boldsymbol{a}-\boldsymbol{b P x}) d P \boldsymbol{x}$ snerate economic value. Where $\mathrm{VE}$ is the economic valuation per individual per year is used a limited integral calculation, with the upper limit of the highest price of travel expenses (P1) and the lower limit is the lowest cost of travel (P0), whereas (a-bPx) dPx is a demand function where $a$ is constants and bPx is the value of travel cost coefficient.

This research also use SWOT analysis method (Strength, Weakness, Opportunity, and Treath). This analysis use to determine strategies that can be done in the development of tourism based on the strengths, weaknesses of the tourist attraction, and the opportunities and threats of the external environment.
From the multiple linear regression output above, we obtained the equation as follows:

$$
\begin{array}{r}
\mathrm{Y}=-1.472918+0,282346 \boldsymbol{X}_{\mathbf{1}}-0,20023 \\
\boldsymbol{X}_{\mathbf{2}}+0,680432 \boldsymbol{X}_{\mathbf{3}}+0,437841 \boldsymbol{X}_{\mathbf{4}}+\mathrm{e} \ldots \ldots \ldots \ldots \ldots(2)
\end{array}
$$

Based on the output above, Access variable (X1) significantly influences the demand for the visit number of Mawar Basecamp, meaning that when the access variable increases by one percent it will affect the number of demand for the visit of Mawar Basecamp by 0.282346 visits in the end of year.

The result of the income variable (X2) of 0.020023 indicates that if the income goes up by one rupiah then the demand for the visit will be 0.020023 in the end of year. This shows that when visitors have more income they prefer to visit more expensive playground recreational parks or visit similar tourist destinations farther and better than Mawar Basecamp.

Researcher distributing questionnaires to determine the influence of any factors that influence the demand for the number of visits. After distributing the questionnaires, the next step is data tabulation. Which tabulates number of visits demands as the dependent variable and access variables, revenue, motivation and travel costs as independent variables. Furthermore, the significance of the access, income, trip motivation and trip cost to the request of the number of visits of Basecamp Mawar will be done.

\section{RESULTS AND DISCUSSION}

Table 1. Multiple linear regression output

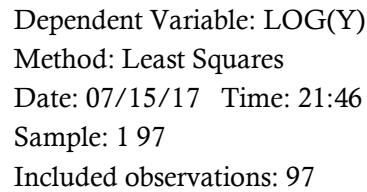

\begin{tabular}{lllll}
\hline \hline Variable & Coefficient & Std. Error & t-Statistic & Prob. \\
\hline \hline C & -1.472918 & 0.459304 & -3.206850 & 0.0018 \\
LOG(X1) & 0.282346 & 0.153694 & 1.837064 & 0.0694 \\
LOG(X2) & 0.020023 & 0.083882 & 0.238703 & 0.8119
\end{tabular}


Muhammad Izzuddin Furqony \& Fafurida/ Economics Development Analysis Journal 6 (4) (2017)

\begin{tabular}{lllll} 
LOG(X3) & 0.680432 & 0.146314 & 4.650490 & 0.0000 \\
LOG(X4) & 0.437841 & 0.133906 & 3.269772 & 0.0015 \\
\hline \hline R-squared & 0.389588 & Mean dependent var & 1.759804 \\
Adjusted R-squared & 0.363049 & S.D. dependent var & 0.305188 \\
S.E. of regression & 0.243568 & Akaike info criterion & 0.063332 \\
Sum squared resid & 5.457950 & Schwarz criterion & 0.196049 \\
Log likelihood & 1.928391 & Hannan-Quinn criter. & 0.116996 \\
F-statistic & 14.67948 & Durbin-Watson stat & 1.683158 \\
Prob(F-statistic) & 0.000000 & & \\
\hline \hline
\end{tabular}

Source : Primary data, 2017 (processed)

Significant test results have been done to determine the effect of access variables, revenue, travel motivation and travel costs, obtained the following regression results:

Variable of travel motivation (X3) valued at 0.680432 shows that when the motivation of travel increased by one percent then the number of requests visit Mawar Basecamp will increase by 0.680432 visits in the end of year. The greater the motivation and purpose of visitors to come then the more visits made by visitors to Mawar Basecamp or coming back.

The variable cost of travel (X4) also positively affects the request of the visit of Mawar Basecamp. A value of 0.437841 indicates that if visitor travel costs increase by one percent then the demand for Mawar Basecamp visit will also increase by 0.437841 visits in the end of year. This condition prove that visitor are feeling happy to enjoy the spot and want to spent more money.

The regression result between the number of visits requests and travel costs generates a demand function as shown in the following equation.

$\mathrm{Y}=3,955081+3,07 \mathrm{E}-06 X_{4}$

$\mathrm{Dx}=\mathrm{Qx}=3,955081+0,00000307 \mathrm{P}$

Based on the results of the equation is used to generate consumer surplus as the economic value. To generate a consumer surplus per individual per year used a limited integral of visitor travel costs. The upper limit is $\mathrm{Rp} 834.000$, - $\left(\mathrm{P}^{\wedge} 1\right)$ and the lower limit is Rp 12.000, - $\left(\mathrm{P}^{\wedge}\right.$ $0)$. To calculate the consumer surplus used the following equation:

$S K=\int_{12.000}^{834.000} 3,955081+0,00000307 p d P$

$=2.278 .099,026 /$ individual per years

$=759.366,342 /$ individual per once visit

Based on the result of the calculation, the consumer surplus per individual per year is $\mathrm{Rp}$ $2,278,099,026$. Visitors who come to Mawar Basecamp on average have visited three times, so it is known surplus that consumers enjoyed by Rp $759,366,342$ per individual per one visit. Visitors who come to Mawar Basecamp on average have visited 3 times to Mawar Basecamp.

So it is known that the advantages enjoyed by visitors because of the willingness to pay them beyond the ability to pay it amounted to $\mathrm{Rp}$ $138,964,-$.

Strength is all of the potential and resources possessed by Mawar Basecamp including in it a relative advantage over competitors and which consumers want to be given to visitors. The main indicator as follows; 1. The beautiful landscape; 2 . Conservation of Natural Resources; 3. Environmental conditions are still preserved; 4 . Locations adjacent to other attractions; 5 . Community management support.

Based on the results of internal identification, the weaknesses are as follows: 1 . The development program are less comprehensive; 2. Insufficient facilities and infrastructure; 3. Promotion is not maximize; 4. Access road to the location is weak; 5. Budget constraints for management.

The identification of external factors resulted in several factors of opportunities as follows: 1. Increased frequency of tourist visits from year to year; 2 . The concept of tourism to nature is hapening; 3 . Opening job opportunities 
for youth villagers around tourism spot; 4 . Schedule event usually helded; 5 . The concept of natural tourism development (ecotourism)

The threats as follows: 1 . Government support that does not exist; 2. Competition with other areas in the development of nature tourism; 3. Natural disasters, such as forest fires that can disrupt forest ecosystems; 4. Environmental pollution due to low awareness of visitors to the environment.

Based on data that has been tabulated based on questionnaires that have been distributed to respondents, then obtained from the rating and weighting as follows.

SWOT calculation results show that the strength factor has a higher value than the weakness and has a better chance than the threat. The value can be seen as follows:

Internal factors strengh - weaknesses $\quad: 1,60$

$-1,40=0,20$

External factors opportunity - threats $\quad: 1,84$ $-1,19=0,65$

Tabel 2. Weight value of IFE and EFE

\begin{tabular}{|c|c|c|c|c|}
\hline No & $\begin{array}{l}\text { INTERNAL FACTOR } \\
\text { STRENGH } \\
\end{array}$ & RATING & WEIGHT & SCORE \\
\hline 1 & The beautiful landscape of Mawar basecamp & 3,21 & 0,11 & 0,35 \\
\hline 2 & Conservation of Natural Resources & 3,03 & 0,10 & 0,31 \\
\hline 3 & Fresh environmental conditions & 3,28 & 0,11 & 0,37 \\
\hline 4 & Near to the other tourism spot & 2,99 & 0,10 & 0,30 \\
\hline 5 & Society support & 2,89 & 0,09 & 0,27 \\
\hline & $\begin{array}{l}\text { TOTAL } \\
\text { WEAKNESS }\end{array}$ & 15,40 & 0,52 & 1,60 \\
\hline 6 & Simple development program & 3,02 & 0,10 & 0,31 \\
\hline 7 & Lack of infrastructure & 2,86 & 0,09 & 0,27 \\
\hline 8 & Lack of promotion & 2,84 & 0,09 & 0,27 \\
\hline 9 & A damaged highway to the location & 3,04 & 0,10 & 0,31 \\
\hline 10 & Lack of budged & 2,79 & 0,09 & 0,25 \\
\hline & TOTAL & 14,54 & 0,48 & 1,40 \\
\hline & TOTAL IFE & 59,88 & 1,00 & 3,00 \\
\hline No & $\begin{array}{l}\text { EXTERNAL FACTORS } \\
\text { OPPORTUNITY }\end{array}$ & RATING & ВОВОТ & SKOR \\
\hline 1 & A dramatical increase of visitors each years & 3,20 & 0,12 & 0,39 \\
\hline 2 & A happening natural tourism model & 3,30 & 0,13 & 0,41 \\
\hline 3 & Open a job vacancy for young peoples & 3,27 & 0,12 & 0,41 \\
\hline 4 & Several even already helded & 2,65 & 0,09 & 0,25 \\
\hline 5 & Ecotourism concept & 3,17 & 0,12 & 0,38 \\
\hline & TOTAL & 15,59 & 0,58 & 1,84 \\
\hline 6 & $\begin{array}{l}\text { THREATS } \\
\text { A competition with other region to develop the } \\
\text { tourism spot }\end{array}$ & 2,89 & 0,11 & 0,31 \\
\hline 7 & Lack of governmrnt support & 2,70 & 0,10 & 0,26 \\
\hline 8 & Natural disaster & 2,71 & 0,10 & 0,26 \\
\hline
\end{tabular}




\begin{tabular}{lllll}
\hline 9 & Environmental pollution due to the lack of & & & \\
visitorawareness & 3,09 & 0,12 & 0,36 \\
TOTAL & 11,40 & 0,42 & 1,19 \\
TOTAL EFE & 42,58 & 1,00 & 3,03 \\
\hline
\end{tabular}

The result values are then incorporated into the Grand Strategy Matrix to see the position of the Mawar Basecamp, so that later can be known the right strategy for the development of Mawar Basecamp like what. Based on the above values, the position in the Grand Strategy Matrix is in the quadrant to one that supports aggressive strategy for proper development, as in the following figure:

Based on the results of the analysis in Table 4, four possible strategies for the development of Mawar Basecamp are based on the potential and environmental conditions as shown in Table 4. Where the strategy is as follows; 1 . Improve the positive image of tourists to Mawar Basecamp as a natural tour; 2 . Development and improvement of the quality of existing tourism products to be more interesting; 3. Maintain and control the preservation of the natural ecosystem and the Basecamp environment; 4. Optimization of website and social media as a media campaign; 5 . Following various promotional events and tourism cooperation; 6. Improvement of access and improvement of facilities and infrastructure; 7. Training and quality improvement of human resource management on a regular basis; 8 . Increased cooperation with various business sectors for the development of Mawar Basecamp; 9. Increased surveillance of visitors who come camping or mountain climbing; 10. Provision of waste bins in various strategic positions to avoid pollution of the environment by visitors; 11 . Cooperate with the Department of Tourism to cooperate in the development, capital, promotion and training of human resources for managers; 12. Installation of various signboards regarding environmental protection in order to avoid the destruction of visitors; 13. Arrangement of management of Basecamp according to problems owned.

Figure 2. Grand Strategy Matrix

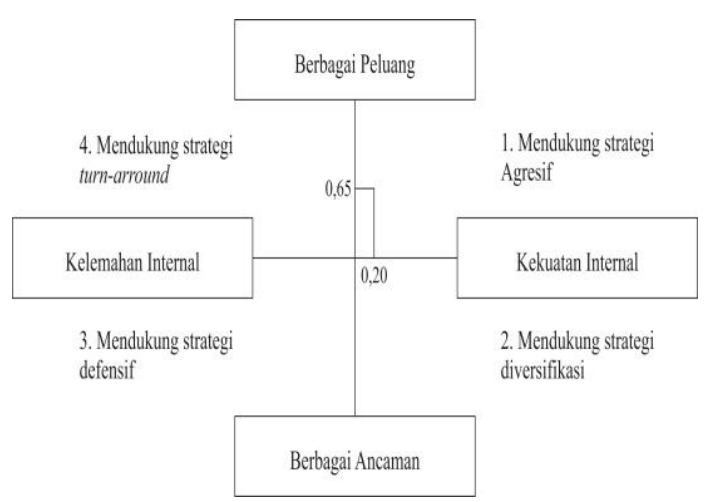

Based on Figure 2, the position of the Mawar Basecamp is in quadrant 1, this indicates that the Basecamp is in a very favorable position. This position shows that the Basecamp has the dominant opportunity and strength compared to the existing weaknesses and threats. The strategy applied in this condition is to support an aggressive growth strategy (growth oriented strategy).

Based on the IFE and EFE tables and the grand strategy matrix that has been done then further done the determination of appropriate strategies to support aggressive growth strategy.

Table 2. Mawar Basecamp Development Strategy

\begin{tabular}{|l|l|l|}
\hline Internal factors (IFAS) & Strengh (S) & Weaknesses (W) \\
\cline { 2 - 3 } & $\begin{aligned} \text { 1. The beautiful landscape of } \\
\text { Mawar basecamp }\end{aligned}$ & $\begin{array}{l}\text { 1. Simple development } \\
\text { program }\end{array}$ \\
& $\begin{array}{l}\text { 2. Conservation of Natural } \\
\text { Resources that is still awake }\end{array}$ & $\begin{array}{l}\text { 2. Lack of infrastructure } \\
\text { 3. Lack of promotion }\end{array}$ \\
& 3. Fresh environmental conditions & \\
\hline
\end{tabular}




\begin{tabular}{|c|c|c|}
\hline External factors (EFAS) & $\begin{array}{l}\text { 4. Near to the other tourism spot } \\
\text { 5. Society support }\end{array}$ & $\begin{array}{l}\text { 4. A damaged highway to } \\
\text { the location } \\
\text { 5. Lack of budged }\end{array}$ \\
\hline Opportunity (O) & Strategy SO & Strategy WO \\
\hline $\begin{array}{l}\text { 1. A dramatical increase of } \\
\text { visitors each years } \\
\text { 2. A hapening natural } \\
\text { tourism model } \\
\text { 3. Open a job vacancy for } \\
\text { young peoples } \\
\text { 4. Several even already } \\
\text { helded } \\
\text { 5. Ecotourism concept }\end{array}$ & $\begin{array}{l}\text { 1. Improve the positive image } \\
\text { of tourists to Mawar } \\
\text { Basecamp as a natural tour } \\
\text { 2. Development and } \\
\text { improvement of the quality } \\
\text { of existing tourism products } \\
\text { to be more interesting } \\
\text { 3. Maintain and control the } \\
\text { preservation of the natural } \\
\text { ecosystem and the Mawar } \\
\text { Basecamp environment }\end{array}$ & 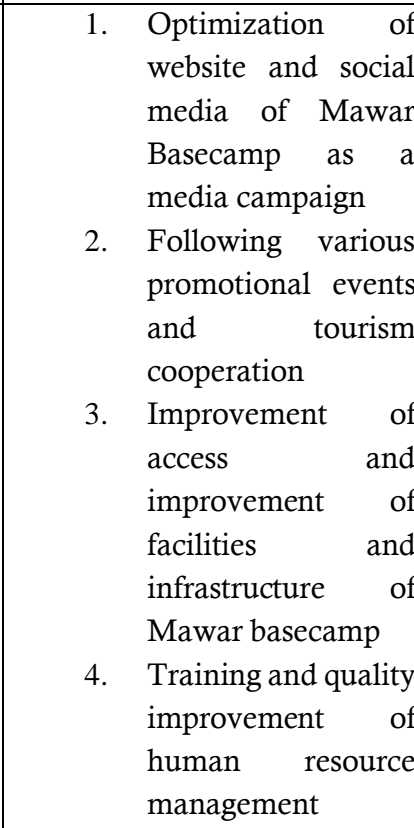 \\
\hline Threat (T) & Strategy ST & Strategy WT \\
\hline $\begin{array}{l}\text { 1. A competition with other } \\
\text { region to develop the } \\
\text { tourism spot } \\
\text { 2. Lack of governmrnt } \\
\text { support } \\
\text { 3. Natural disaster } \\
\text { 4. Environmental pollution } \\
\text { due to the lack of visitor } \\
\text { awareness }\end{array}$ & $\begin{array}{l}\text { 1. Increased cooperation with } \\
\text { various business sectors for the } \\
\text { development of Mawar } \\
\text { Basecamp } \\
\text { 2. Increased surveillance of visitors } \\
\text { who come camping or mountain } \\
\text { climbing } \\
\text { 3. Provision of waste bins in } \\
\text { various strategic positions to } \\
\text { avoid pollution of the } \\
\text { environment by visitors; }\end{array}$ & $\begin{array}{l}\text { 4. Cooperate with the } \\
\text { Department of Tourism } \\
\text { to cooperate in the } \\
\text { development, capital, } \\
\text { promotion and training } \\
\text { of human resources for } \\
\text { managers } \\
\text { 5. Installation of various } \\
\text { signboards regarding } \\
\text { environmental protection } \\
\text { in order to avoid the } \\
\text { destruction of visitors } \\
\text { Arrangement of } \\
\text { management of Mawar } \\
\text { Basecamp according to } \\
\text { problems owned. }\end{array}$ \\
\hline
\end{tabular}




\section{CONCLUSION}

There are some dependent variables in the research that significantly influence the number of requests visit Basecamp namely independent variables access, travel motivation and travel costs have a significant positive effect on the dependent variable demand the number of visits. While the independent variables of income have a significant negative effect on the number of requests visit.

Based on the result of economic valuation analysis, the surplus of tourist consumers is $\mathrm{Rp}$ $2,278,099,026$ per individual per year or $\mathrm{Rp}$ $759,366,342$ per one visit. This indicates that the amount of benefits obtained by tourists exceeds the average travel costs to be incurred tourists amounting to $\mathrm{Rp} 138,964$ per visit. Based on the calculation for the total economic value of Mawar Basecamp through individual travel cost approach, the total value of Basecamp economy is $\mathrm{Rp} 8,212,546,988,73$ per year.

Based on the result of SWOT analysis that has been done, it can be concluded that the development strategy that can be done for Mawar Basecamp development through aggressive growth strategy is to improve and organize all facilities and services of visitors in order to maintain the positive image of Basecamp as nature tour, maintain and protect the natural conservation, optimize promotion and cooperation with various parties for the development.

\section{REFERENCES}

Arikunto, Suharsimi. 2010. Procedure Research An Applied Approach. Jakarta. Rineka Cipta.

Central Statistics Agency of Semarang Regency. 2016: Semarang Dalam Angka 2016

Hermansyah and Busori Sunaryo. 2016. Development of Marine Ecotourism Bontang Kuala Through Community Development PT Badak NGL. Economics Development Analysis Journal, Vol 5 No.1 / 2016

Baskoro, Dwi Hary. 2013. Analysis of Lawang Sewu Tourism Object in Semarang City. Essay. Faculty of Economics and Business. Diponegoro University.
Eriyati, Syapsan, Aqualdo, N. 2017. Analysis of Tourism Object Demand in The Pekanbaru City With Travel Cost Method. International Journal of Scientific \& Technology Research, 6(11).

Fathurrahmi, Fitri. 2016. Analysis of Factors Affecting Tourist Demand in Gandoriah Beach Tourist Objects Pariaman City. Essay. Faculty of Economics. Andalas University.

Gillespie, R., Collins, D., Bennett, J. 2017. Adapting the travel cost method to estimate changes in recreation benefits in the Hawkesbury-Nepean River. Australasian Journal of Environmental Management 24(4).

Mirela, M., Robuntu, C., Marinescu, R. 2017. New Products and Strategies for Sustainable Tourism in Romania. Journal of Tourism \& Hospitality, 6(5).

Indah, Irma Afia Salma and Susilowati. 2004. Request Analysis of Nature Tourism Curug Sewu. Kendal Regency with Travel Cost Approach. Journal. Journal of Development Dynamics, Vol. 2 / Dec 2004.

Hang on, Freddy. 2015. Engineering Dissecting Business Cases SWOT Analysis. Jakarta: PT Gramedia Pustaka Utama.

Yoeti, O. A. 1982. Introduction to Tourism Science. Bandung: Angkasa. 